\title{
PENGARUH PEMBERIAN KOMBINASI KUERSETIN DAN GLIBENKLAMID TERHADAP KADAR KOLESTEROL LDL PADA TIKUS DIABETES MELITUS TIPE 2
}

\author{
Monika, A.M. ${ }^{1}$, Lestariana, $\mathrm{W}^{2}$ \\ ${ }^{1}$ MahasiswaFakultas Kedokteran Universitas Islam Indonesia \\ ${ }^{2}$ Departemen Biokimia Fakultas Kedokteran Universitas Islam Indonesia
}

\begin{abstract}
ABSTRAK
Latar belakang

Stres oksidatif telah diketahui berperan dalam patogenesis diabetes melitus (DM), termasuk penyakit jantung koroner (PJK) sebagai salah satu komplikasi tersering. Kuersetin adalah salah satu kelompok flavonoid alami yang banyak tersebar dalam tumbuhan dan dapat bekerja sebagai antioksidan. Penelitian sebelumnya menunjukkan bahwa kuersetin dapat mencegah komplikasi dan mengontrol kolesterol LDL pada DM tipe 2.
\end{abstract}

\section{Tujuan}

Tujuan penelitian ini adalah untuk mengetahui pengaruh kombinasi kuersetin dan glibenklamid terhadap kadar kolesterol LDL pada tikus yang mengalami DM tipe 2.

\section{Metode}

Penelitian ini bersifat eksperimental murni dengan desain kelompok kontrol pre dan posttest. Terdapat 16 tikus diabetes sebagai subjek penelitian yang akan dibagi menjadi 4 kelompok perlakuan; kelompok 1 menerima plasebo, kelompok 2 glibenklamid 5 $\mathrm{mg} / \mathrm{kgBB} /$ peroral, kelompok 3 kuersetin $20 \mathrm{mg} / \mathrm{kgBB} /$ peroral dan kelompok 4 kombinasi keduanya. Perlakuan diberikan selama 4 minggu dan diperiksa perubahan kadar kolesterol LDL yang terjadi.

\section{Hasil}

Kombinasi kuersetin dan glibenklamid menurunkan kadar kolesterol lebih baik secara signifikan dari pada tanpa kombinasi maupun plasebo $(\mathrm{p}<0.05)$. Kuersetin menurunkan kadar kolesterol LDL lebih baik secara signifikan dari pada plasebo $(\mathrm{p}<0.05)$.

\section{Kesimpulan}

Dari hasil penelitian ini dapat disimpulkan bahwa pemberian kombinasi kuersetin dan glibenklamid dapat menurunkan kadar kolesterol LDL lebih baik dari pada tanpa kombinasi maupun plasebo.

\section{Kata Kunci}

Kuersetin, Diabetes melitus tipe 2, Dislipidemia, Kolesterol-LDL, Antioksidan 


\section{ABSTRACT}

Background. Oxidative stress is the major role in pathogenesis of diabetes mellitus which causes many complications. Chronic hyperglycaemia and dyslipidaemia in diabetes mellitus are the causes of oxidative stress. Quercetin is one of natural antioxidant flavonoid which widely distributed in many plants. Earlier studies showed that quercetin could prevent some complications and controlled LDL cholesterol level in type 2 diabetes mellitus.

Objective. The aim of this research was to investigate the effects of quercetin which combined with glibenclamide to LDL-cholesterol level in type 2 diabetic rats.

Methods. The rats were injected by streptozotocin and nicotinamide intraperitoneally. Then, they were randomly divided to four groups (each group consisted of four rats): group 1 received placebo (aquades) orally, group 2 received glibenclamide $(5 \mathrm{mg} / \mathrm{kg}$ body weight) orally, group 3 received quercetin $(20 \mathrm{mg} / \mathrm{kg}$ body weight) orally, and the last group 4 received the combination of quercetin and glibenclamide orally. After 4 weeks, plasma was taken and examined for the cholestreol-LDL level.

Results. Quercetin combined with glibenclamide significantly decreased plasma concentration of cholesterol-LDL level better than no combination or placebo $(p<0.05)$. Quercetin significantly decreased plasma concentration of cholesterol-LDL level better than or placebo $(p<0.05)$.

Conclusion. Quercetin combined with glibenclamide significantly decreased plasma concentration of cholesterol-LDL level better than no combination or placebo.

KEYWORDS: Quercetin, Type 2 Diabetes Mellitus, Dyslipidemia, LDL-cholesterol, Antioxidant

\section{PENDAHULUAN}

Diabetes melitus (DM) telah menjadi masalah global di negara maju maupun berkembang. Berdasarkan data penelitian terakhir, sampai saat ini terdapat 347 juta penderita diabetes di seluruh dunia, dengan $90 \%$ di antaranya mengalami DM tipe $2{ }^{1}$ Indonesia menjadi salah satu negara dengan jumlah penderita diabetes yang cukup tinggi, bahkan menurut Tandra (2008) Indonesia bisa menempati peringkat ke-5 di dunia pada tahun 2025. ${ }^{2}$ Diabetes dan komplikasinya dapat menyebabkan penurunan kualitas hidup penderita, mengurangi masa produktif penduduk dan secara tidak langsung membebani negara dengan penyelenggaraan biaya kesehatan yang lebih besar.

WHO (2013) memprediksi angka kematian yang disebabkan oleh diabetes akan meningkat sampai $50 \%$ pada tahun 2030, sekaligus menjadi 'penyakit pembunuh nomor tujuh di dunia. Faktor yang paling banyak memengaruhi tingginya angka kematian pada penderita DM adalah komplikasi vaskular yang terjadi akibat 
pengelolaan yang kurang baik. Dari sekian banyak komplikasi yang disebabkan oleh diabetes, penyakit jantung koroner (PJK) menjadi salah satu penyebab kematian dan kesakitan utama pada pasien DM. ${ }^{3}$ Angka kejadian PJK pada DM berkisar antara 45$70 \% .^{4}$ Salah satu faktor risiko yang memengaruhi terjadinya PJK adalah dislipidemia. $^{5}$

Dislipidemia adalah kelainan metabolisme lipid yang ditandai dengan peningkatan maupun penurunan fraksi lipid dalam plasma. Dalam sebuah penelitian ditemukan $60 \%$ penderita diabetes mengalami dislipidemia dengan kadar kolesterol LDL $\geq 130 \mathrm{mg} / \mathrm{dl}$ dan semakin meningkat seiring bertambahnya durasi diabetes yang diderita. $^{6}$ Keadaan hiperglikemia sendiri sebenarnya tidak secara langsung meningkatkan kadar kolesterol LDL dalam darah, akan tetapi pada penderita DM didapatkan partikel LDL berdensitas kecil yang sifatnya lebih aterosklerotik, lebih mudah terglikasi dan mengalami oksidasi sehingga untuk selanjutnya kadar kolesterol LDL dalam darah penderita DM akan semakin meningkat. ${ }^{7} \quad$ Hiperglikemia dapat menyebabkan munculnya oksidan patologis, meningkatkan peroksidasi lipid dan mengganggu jalur sinyal sel seperti fosfolipid atau kinase sehingga meningkatkan stres oksidatif sel. ${ }^{8}$ Oksidan patologis yang sering disebutkan sebagai salah satu penyebab stres oksidatif pada keadaan hiperglikemia kronis adalah reactive oxygen species (ROS). ${ }^{9}$

Saat ini pemanfaatan antioksidan yang berasal dari bahan alam sudah banyak dikembangkan, salah satunya adalah kuersetin yang berasal dari golongan flavonoid. Secara alami kuersetin terkandung di dalam buah dan sayuran seperti apel, anggur, bawang putih, kacang, biji-bijian, teh, tomat dan lainnya. Pemberian kuersetin pada hewan coba menunjukkan adanya efek perlindungan terhadap otak, jantung dan jaringan lain untuk melawan dampak cedera iskemik, komponen toksik dan faktor lainnya yang dapat menginduksi stres oksidatif. ${ }^{10}$ Efek protektif ini juga berpengaruh pada sel $\beta$ pankreas sehingga sekresi insulin dapat ditingkatkan. ${ }^{11}$ Oleh karena itu, pada penelitian ini perlu diperiksa potensi kuersetin terhadap penurunan kadar kolesterol LDL dan diuji pula jika dikombinasikan dengan glibenklamid sebagai obat hipoglikemik oral (OHO) yang sering digunakan. 


\section{METODE PENELITIAN}

Penelitian menggunakan rancangan penelitian eksperimental murni dengan kelompok kontrol pre dan post-test. Penelitian dilakukan di Laboratorium Pusat Antar Universitas (PAU) UGM. Waktu penelitian mulai bulan Maret sampai Juni 2013. Populasi adalah enam belas tikus putih (Rattus norvegicus) galur Wistar jantan berusia 12-16 minggu dengan berat badan 200-300 gram. Etika penelitian terhadap hewan diajukan ke Komisi Etik Penelitian Kesehatan dan Kedokteran FK UGM. Cara penelitian adalah tikus yang memenuhi kriteria dan sehat diadaptasi selama 1 minggu kemudian diinduksi dengan injeksi streptozotocin dosis 60 $\mathrm{mg} / \mathrm{kgBB}$ sekali pemberian dan nicotinamide dosis $120 \mathrm{mg} / \mathrm{kgBB}$ sekali pemberian secara intraperitoneal. Setelah dinyatakan mengalami DM (kadar gula darah puasa $\geq 126 \mathrm{mg} / \mathrm{dL}$ minimal 1 minggu setelah induksi), tikus kemudian diperiksa kadar kolesterol LDL nya. Setelah itu subjek dibagi menjadi 4 kelompok; kelompok 1 adalah kelompok kontrol yang mendapat plasebo (akuades), kelompok 2 mendapat glibenklamid $5 \mathrm{mg} / \mathrm{kgBB} / \mathrm{hari}$, kelompok 3 mendapat kuersetin 20 $\mathrm{mg} / \mathrm{kgBB} /$ hari dan kelompok 4 mendapat kombinasi keduanya. Perlakuan diberikan selama 4 minggu peroral menggunakan sonde dan di akhir waktu tersebut diperiksa kadar kolesterol LDL masing-masing tikus. Pemeriksaan sampel darah dilakukan di Laboratorium Biokimia FK UGM. Nilai normal kadar kolesterol LDL adalah 7-27,2 mg/dL. Pengukuran kadar kolesterol LDL dan gula darah puasa menggunakan metode spektrofotometri. Data disajikan dalam bentuk rerata dan simpangan baku, median dan nilai p. Untuk membandingkan kadar kolesterol LDL sebelum dan sesudah perlakuan dalam satu kelompok dilakukan dengan uji-t berpasangan $(\mathrm{p}<0,05)$, sedangkan untuk membandingkan antar kelompok dilakukan uji Multivariate ( $\mathrm{p}<$ $0,05)$.

\section{HASIL DAN PEMBAHASAN}

Berdasarkan analisis data menggunakan One Way Anova, dapat disimpulkan bahwa kadar kolesterol LDL tikus DM setelah 4 minggu perlakuan memiliki perbedaan yang bermakna antar kelompok $\quad(\mathrm{p}=0,000)$. Demikian juga dengan hasil uji Multivariate yang menunjukkan bahwa terdapat perbedaan yang bermakna antara hasil pre-test dan post-test pada masing-masing kelompok jika dibandingkan antar kelompok $(\mathrm{p}=0,000)$. Pada Gambar. 1 terlihat pada 


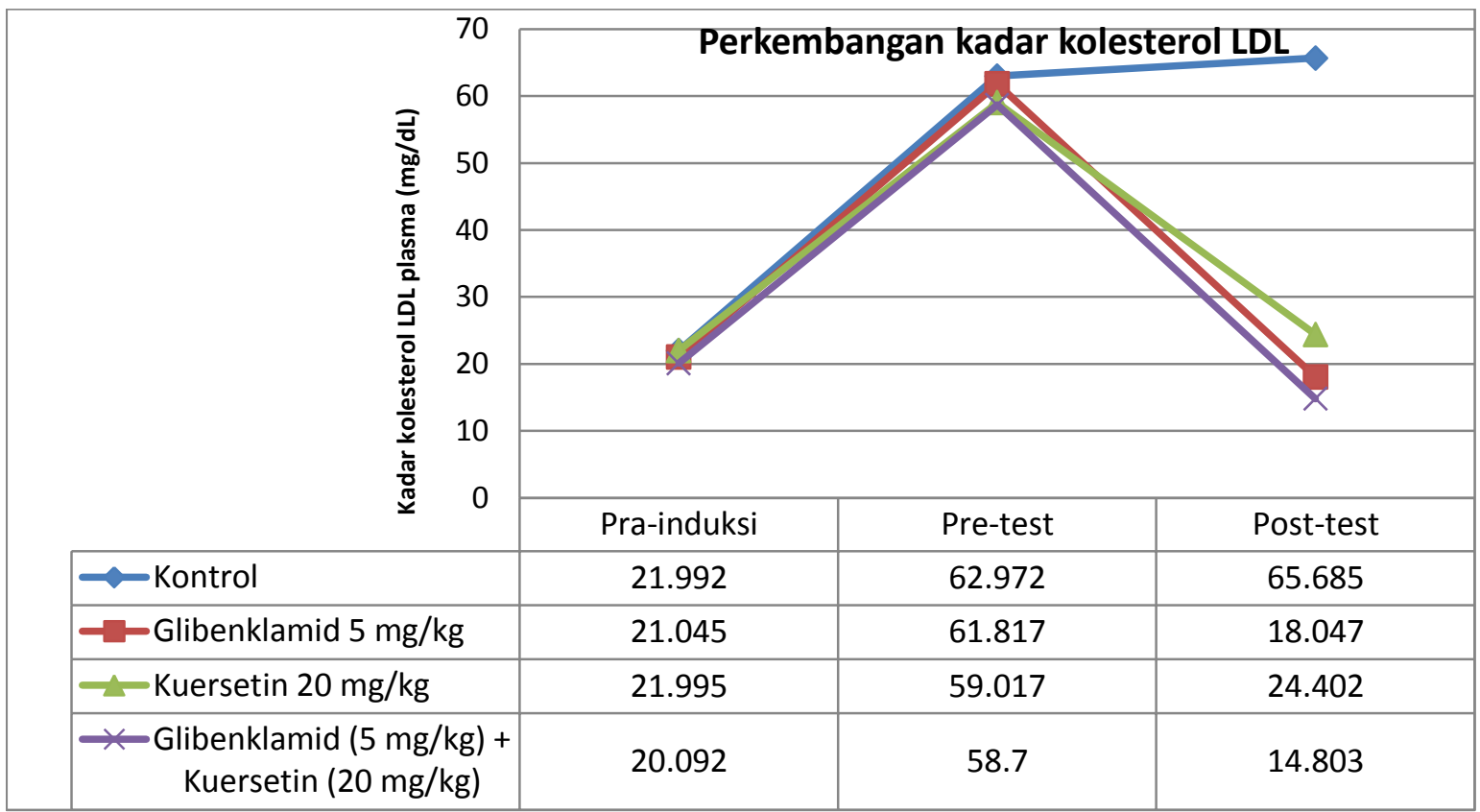

Gambar 1. Kurva rerata kadar kolesterol LDL versus waktu pemeriksaan

kelompok 1 yang mendapat plasebo dengan obat hipoglikemik standar mengalami peningkatan rerata kadar glibenklamid lebih efektif menurunkan kolesterol LDL. Sedangkan pada kelompok kadar LDL jika dibandingkan tanpa 2 yang mendapat glibenklamid 5 kombinasi maupun plasebo. $\mathrm{mg} / \mathrm{kgBB} /$ hari, kelompok 3 yang mendapat Hasil penelitian di atas sekilas kuersetin $20 \mathrm{mg} / \mathrm{kgBB} /$ hari dan kelompok tampak sesuai dengan hasil penelitian4 yang mendapat kombinasi keduanya penelitian sebelumnya yang menunjukkan mengalami penurunan kadar kolesterol bahwa kuersetin dapat menurunkan kadar LDL secara bermakna pada pengukuran pos kolesterol LDL pada tikus diabetes. tes. Pada uji perbedaan rerata kolesterol LDL antar kelompok pada pengukuran pos tes didapatkan kelompok 4 yang diberi kombinasi kuersetin dan glibenklamid memiliki rerata kadar LDL serum lebih rendah secara bermakna dibandingkan kelompok yang lain. Hal ini menunjukkan bahwa kuersetin yang dikombinasikan Penelitian sebelumnya menunjukkan bahwa kuersetin memiliki efek hipolipidemik pada tikus DM yang diinduksi dengan streptozotocin. $^{12,13}$ Pemberian kuersetin dengan dosis $15-50 \mathrm{mg} / \mathrm{kgBB}$ terbukti dapat menurunkan kadar kolesterol LDL pada tikus DM yang diinduksi dengan aloksan. ${ }^{14}$ Kuersetin dapat memperbaiki keadaan 
dislipidemia dengan meningkatkan ekspresi peroxisome proliferator-activated receptor$\gamma$ (PPAR- $\gamma$ ) dan menurunkan ekspresi sterol regulatory element-binding protein 1c (SREBP-1c) pada hati tikus sehingga menurunkan sintesis trigliserida, pembentukan asam lemak bebas secara de novo dan aktivitas acetyl-CoA carboxylase (ACC) di hepatosit tikus. ${ }^{15,16}$ PPAR- $\gamma$ adalah faktor transkripsi penting dan paling sering diteliti dibanding dengan subtipe $\alpha$ maupun $\beta$. Diperkirakan kuersetin dapat menjadi ligand yang mampu mengikat reseptor tersebut sehingga dapat mengendalikan transkripsi resistin atau gen sel adiposa lainnya yang memengaruhi resistensi insulin. ${ }^{17}$ Selain itu, kuersetin juga dapat mengurangi resistensi insulin pada model hewan diabetes dengan cara meningkatkan kadar hormon adiponektin yang dihasilkan oleh jaringan adiposa. ${ }^{15}$ Sedangkan untuk menangani stres oksidatif yang terbentuk pada penderita diabetes dan menyebabkan perubahan pada oksidasi lipoprotein, kuersetin bekerja dengan "memakan" radikal bebas dan ROS secara langsung serta meningkatkan aktivitas enzim-enzim antioksidan seperti SOD, CAT, dan GSH-Px. Kuersetin bisa menjadi scavenger kuat terhadap ROS dan radikal bebas lainnya karena memiliki kelompok hidroksil aromatik. ${ }^{18}$ Dengan cara kerja tersebut, kuersetin dapat membuat LDL menjadi lebih resisten terhadap oksidasi dan menurunkan kejadian aterosklerosis yang dapat berkembang menjadi penyakit jantung koroner.

Selain kuersetin, glibenklamid juga menunjukkan kemampuannya dalam menurunkan kadar kolesterol LDL pada tikus diabetes. Glibenklamid pernah diteliti dapat menginhibisi akumulasi kolesterol ester intraselular yang diinduksi oleh LDL terasetil atau LDL teroksidasi di dalam sel J774, tetapi efeknya tidak begitu baik pada kadar kolesterol total, sehingga dapat diperkirakan traget glibenklamid adalah acyl-CoA cholesterol acyltransferase (ACAT) ${ }^{19}$ Lebih jauh, glibenklamid dapat menginhibisi aktivitas ACAT dari sel THP1 yang distimulasi oleh PMA ke sel THP-1 yang tidak berdiferensiasi. Sehingga pada saat itu glibenklamid diperkirakan bisa menjadi inhibitor ACAT. $^{20}$ Selain itu, secara mendasar glibenklamid juga bekerja dengan cara mengoptimalkan sekresi insulin dengan cara terikat pada sulfonylurea receptor-1 (SUR-1), sehingga insulin yang diproduksi dapat menghambat lipolisis pada jaringan adiposa dan otot serta menurunkan produksi VLDL yang diubah menjadi LDL. Meskipun begitu, 
pengobatan glibenklamid sebagai terapi tunggal memiliki keterbatasan karena pada setengah penderita DM tipe 2, kontrol glikemik dan insulin baru tercapai pada tahun ke 6-9. Hal ini memperlihatkan bahwa terdapat konsistensi kerusakan pada sel beta pankreas selama mendapat terapi tunggal akibat stres oksidatif yang terjadi sehingga pemberian kuersetin sebagai kombinasi atau pendamping $\mathrm{OHO}$ akan memberikan hasil yang lebih baik seperti yang tampak pada kelompok yang mendapat kombinasi kuersetin dan glibenklamid. ${ }^{21}$

Pada kelompok yang mendapat kuersetin, pengaruh kuersetin terhadap penurunan kolesterol LDL tidak signifikan jika dibandingkan dengan kelompok yang mendapat glibenklamid (diuji dengan uji Multivariate, $\mathrm{p}$ value $>0,05)$. Berdasarkan kemampuan kuersetin menurunkan kadar kolesterol LDL dan GDP yang tidak lebih baik dibanding glibenklamid menunjukkan bahwa tikus DM tetap membutuhkan pendorong sekresi insulin untuk memperbaiki keadaan hiperglikemia, karena kuersetin hanya bekerja sebagai penghambat terjadinya stres oksidatif yang dapat memperparah kerusakan islet pankreas. Jika cara kerja kuersetin yang dibidik dalam penelitian ini adalah hal tersebut, waktu pemberian kuersetin yang tepat sepertinya dapat mempengaruhi hasil penelitian sekarang. Pertama, kuersetin yang diberikan bersifat lipofilik, sehingga akan lebih baik jika diberikan bersama makanan yang mengandung lemak. Akan tetapi dalam penelitian ini terkadang kuersetin diberikan dalam kondisi tikus belum mengonsumsi makanan, sehingga faktor ini menjadi salah satu keterbatasan penelitian. Dari beberapa penelitian sebelumnya, pemberian kuersetin 15 $\mathrm{mg} / \mathrm{kgBB} /$ hari selama 28 hari terbukti dapat menurunkan kadar glukosa darah secara signifikan serta meningkatkan produksi dan aktivitas antioksidan dari enzim SOD, GSHPx dan CAT yang nantinya akan memperbaiki profil lipid plasma tikus yang diinduksi dengan streptozotocin. ${ }^{22}$ Hanya saja cara pemberian kuersetin pada penelitian tersebut dengan penelitian sekarang cukup berbeda yaitu kuersetin diberikan 3 hari sebelum diinduksi dan dilanjutkan 25 hari setelah hasil induksi berhasil. Pemberian kuersetin sebelum induksi terbukti mampu memperbaiki status antioksidan dalam tubuh sehingga kadar glukosa darah tikus dapat terkontrol. Sedangkan pada penelitian sekarang, sebelum induksi tidak diberikan kuersetin terlebih dahulu. Pada penelitian yang sama, 
cara pemberian kuersetin juga berbeda Pada penelitian yang lain juga disebutkan karena diberikan dengan injeksi bahwa kuersetin dengan dosis 15 intraperitoneal, sedangkan pada penelitian $\mathrm{mg} / \mathrm{kgBB} / \mathrm{hari}$ yang disuntikkan secara sekarang kuersetin diberikan per oral intraperitoneal pada tikus setara dengan melalui sondase. Kuersetin yang diberikan $1000 \mathrm{mg}$ untuk manusia seberat $70 \mathrm{~kg}^{22}$ peroral diabsorpsi dengan kurang baik oleh Akan tetapi jika kuersetin diberikan per oral saluran pencernaan sehingga pengaruh yang diharapkan tidak maksimal. ${ }^{23}$

Aksi kuersetin dalam menurunkan kadar kolesterol LDL juga bisa bergantung pada beberapa faktor endogen. Salah satunya adalah seberapa besar aktivasi beberapa enzim mikrosomal pada tubuh hewan coba, seperti P450 sitokrom yang terbukti meningkat pada kelompok kuersetin. $^{24}$ Telah diketahui bahwa 7hidroksilase yang bergantung dengan P450 sitokrom terlibat dalam metabolisme kolesterol, dimana kolesterol akan dikonversi ke asam empedu oleh enzim tersebut. Banyaknya dosis kuersetin yang diberikan juga dapat berpengaruh pada penelitian ini. Penelitian sebelumnya telah berhasil dengan menggunakan kuersetin dosis $52 \mathrm{mg} / \mathrm{kgBB} / \mathrm{hari}$ dan 105 $\mathrm{mg} / \mathrm{kgBB} /$ hari selama 6 minggu, dimana kedua dosis tersebut dapat menurunkan kadar gula darah secara signifikan. Sedangkan penurunan kolesterol total dan kolesterol HDL hanya terjadi secara signifikan pada dosis $105 \mathrm{mg} / \mathrm{kgBB} /$ hari. $^{25}$ tentu konsentrasinya akan lebih kecil karena kuersetin hanya akan diabsorpsi $52 \%$ nya saja. Sehingga dalam penelitian ini dosis yang sebaiknya diberikan minimal 30-50 mg/kgBB/hari, didukung dengan penelitian lainnya yang membuktikan bahwa dosis $50 \mathrm{mg} / \mathrm{kgBB} /$ hari lebih sering memberikan hasil yang optimal. ${ }^{26,27}$

Berdasarkan ulasan di atas, secara statistik penelitian ini menunjukkan bahwa kuersetin bisa menurunkan kadar kolesterol LDL pada tikus putih (Rattus norvegicus) galur Wistar jantan yang mengalami DM tipe 2 dengan induksi STZ-NA, terutama pada kelompok yang diberikan kombinasi kuersetin dan glibenklamid. Akan tetapi perlu diperhatikan keterbatasan penelitian yang telah penulis sebutkan untuk melihat hubungannya dengan efek kuersetin terhadap variabel lain.

\section{KESIMPULAN}

Berdasarkan hasil penelitian ini, kuersetin yang dikombinasikan dengan glibenklamid terbukti mampu menurunkan 
kadar kolesterol LDL tikus putih (Rattus norvegicus) galur Wistar jantan yang mengalami DM tipe 2 dengan induksi streptozotocin-nicotinamide secara signifikan lebih baik dari pada tanpa kombinasi maupun plasebo. Kuersetin saja terbukti dapat menurunkan kadar kolesterol LDL lebih baik secara signifikan dari pada plasebo.

\section{SARAN}

Perlu dilakukan penelitian lebih lanjut tentang efek pemberian kombinasi kuersetin dan glibenklamid terhadap variabel profil lipid yang lain seperti HDL, trigliserid atau kolesterol total dengan pengendalian yang lebih ketat terhadap beberapa faktor yang berperan terhadap profil lipid dan kadar gula darah.

\section{DAFTAR PUSTAKA}

1. World Health Organization. 10 facts about diabetes. 2012. http://www.who.int/features/factfiles/diabete s/facts/en/index1.html, diakses pada 7 Juli 2013.

2. Utomo OM, Azam M, Anggraini DN. Pengaruh senam terhadap kadar gula darah penderita diabetes. Unnes Journal of Public Health 2012:1.

3. Stefani S. Prevalensi dan Faktor Risiko Penyakit Jantung Koroner Pada Penderita Diabetes Melitus Tipe 2 Di Rumah Sakit Immanuel Bandung Periode JanuariDesember 2010. Jurusan Pendidikan Dokter
Fakultas Kedokteran, Universitas Kristen Maranantha 2011.

4. Majid A. Penyakit jantung koroner: patofisiologi, pencegahan, dan pengobatan terkini. USU 2007;1-54.

5. Supriyono M. Faktor-Faktor Risiko Kejadian Penyakit Jantung Koroner (PJK) Pada Kelompok Usia < 45 Tahun. (Studi Kasus di RSUP Dr. Kariadi Semarang dan RS Telogorejo Semarang). Program Master Epidemiologi Fakultas Kedokteran, Universitas Diponegoro 2008.

6. Soewondo P, Soegondo S, Suastika K, Pranoto A, Soeatmadji DW, Tjokroprawiro A. The DiabCare Asia 2008 study Outcomes on control and complications of type 2 diabetic patients in Indonesia. Med J Indonesia 2010;19:235-44.

7. Jameson JL, et al. Harrison's Endocrinology. New York: McGraw-Hill Medical Publishing Division, 283-331, 2006.

8. Goh SY, Cooper ME. The role of advanced glycation end products in progression and complications of diabetes. J Clin Endocrinol Metab. 2008; 93:1143-52.

9. Murarka S, Movahed MR. Diabetic cardiomyopathy. J Card Fail 2010; 16: 9719.

10.Kelly GS. Quercetin. Altern Med Rev. 2011;16(2).

11. Youl E, Bardy G, Magous R. Quercetin potentiates insulin secretion and protects INS-1 pancreatic $\beta$-cells against oxidative damage via the ERK1/2 pathway. Br J Pharmacol. 2010; 161:799-814.

12.Vessal M, Hemmati M, Vasei M. Antidiabetic effects of quercetin in streptozocin-induced diabetic rats. Comp Biochem Physiol C Toxicol Pharmacol. 2003; 135C:357-64.

13.Torres-Piedra M, Ortiz-Andrade R, Villalobos-Molina R, Singh N, MedinaFranco JL, Webster SP, Binnie M, 
Navarrete-Vázquez G, Estrada-Soto S. A comparative study of flavonoid analogues on streptozotocin-nicotinamide induced diabetic rats: quercetin as a potential antidiabetic agent acting via 11betahydroxysteroid dehydrogenase type 1 inhibition. Eur J Med Chem. 2012; 45:260612.

14.Zapolska-Downar D, Kosmider A, Naruszewicz M. Flavonoids-rich extract from chokeberry fruits inhibits oxLDLinduced apoptosis of endothelial cells. Atherosclerosis (Suppl). 2006; 7:223-4.

15.Kobori M, Masumoto S, Akimoto Y, Oike H. Chronic dietary intake of quercetin alleviates hepatic fat accumulation associated with consumption of a Westernstyle diet in C57/BL6J mice. Mol Nutr Food Res. 2011; 55:530-40.

16.Gnoni GV, Paglialonga G, Siculella L. Quercetin inhibits fatty acid and triacylglycerol synthesis in rat-liver cells. Eur J Clin Invest. 2009;39:761-8.

17.Fang K, Gao J, Zhu DN. Kaempferol and quercetin isolated from Euonymus alatus improve glucose uptake of 3T3-L1 cells without adipogenesis activity. Life Sci. 2008; 82:615-22.

18.Du Thie G, Crozier A. Plant derived phenolic antioxidants. Curr Opin Clin Nutr Metab. 2000; 3: 447-51.

19. Mirbadalzadeh R, Shirdel Z. Antihyperglycemic and Antihyperlipidemic effects of Cornus mas extract in diabetic rats compared with glibenclamide. Elixir Hormo. \& Signal 2012; 47:8969-72.

20.Ohgami N, Kuniyasu A, Furukawa K, Miyazaki A, Hakamata H, Horiuchi S, Nakayama H. Glibenclamide Acts as an Inhibitor of Acyl-CoA:Cholesterol Acyltransferase Enzyme. Biochem\&Biophys Res Comm. 2007; 277:2:417-22.

21.Wright A, Burden ACF, Paisey RB, Cull CA, Holman RR. Sulfonylurea inadequacy: efficacy of addition of insulin over 6 years in patients with type 2 diabetes in the UK Prospective Diabetes Study (UKPDS 57). Diabetes Care 2002; 25:330-6.

22. Abdelmoaty MA, Ibrahim MA, Ahmad NS, Abdelaziz MA. Confirmatory studies on the antioxidant and antidiabetic effect of quercetin in rats. Ind J. Clin Biochem. 2010;25:2:188-92.

23.Rizk A, Hammouda F, Rimpler H, Kamel A. Iridoids and flavonoids of Teucrium polium herb. Planta Med. 1986; 2: 87-8.

24.Juzwiak, et al. Effect of quercetin on experimental hyperlipidemiaand atherosclerosis in Robbins. Pharm. Reports 2005; 57:604-9.

25.Jeong SM, Kang MJ, Choi HN, Kim JH, Kim JI. Quercetin ameliorates hyperglycemia and dyslipidemia and improves antioxidant status in type 2 diabetic db/db mice. Nutr Res Pract. 2012; 6:3:201-7.

26. Mahesh T, Menon VP. Quercetin alleviates oxidative stress in streptozotocin-induced diabetic rats. Phytoter Res. 2004; 18:123-7.

27. Shetty AK, Rashmi R, Rajan MGR, Sambiah K, Salimath PV. Antidiabetic influence of quercetin in streptozotocininduced diabetic rats. Nutr Res. 2004; 24:373-81. 